\title{
Cholangiocarcinoma Seeding along a Ventriculoperitoneal Shunt Catheter: A Rare Initial Manifestation
}

\section{Metástase cutânea de colangiocarcinoma no trajeto do cateter da derivação ventriculoperitoneal: Relato de caso}

\author{
Barbara Albuquerque Morais ${ }^{1}$ Ricardo Ferrareto Iglesio ${ }^{1}$ Carlo Emanuel Petitto ${ }^{2}$ \\ Fernando Campos Gomes Pinto ${ }^{2}$ Manoel Jacobsen Teixeira ${ }^{3}$ \\ ${ }^{1}$ Neurosurgery Residency, Hospital das Clínicas da Faculdade de

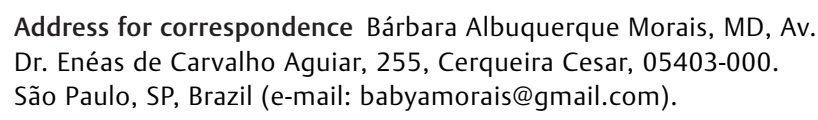
\footnotetext{
Medicina da Universidade de São Paulo (HC-FMUSP), São Paulo, SP, Brazil

2 Hydrodynamics Division, HC-FMUSP, São Paulo, SP, Brazil

${ }^{3}$ Neurosurgery Discipline, HC-FMUSP, São Paulo, SP, Brazil
}

Arq Bras Neurocir 2017;36:243-246

\begin{abstract}
Keywords

- cholangiocarcinoma

- ventriculoperitoneal shunt

- cutaneous metastasis
\end{abstract}

\section{Resumo}

Cholangiocarcinoma accounts for less than $2 \%$ of all malignant neoplasms. Its cutaneous metastases are extremely rare, accounting for $0.0002 \%$ of all cases.

The ventriculoperitoneal (VP) shunt has been considered a potential route for tumor dissemination. This type of tumor proliferation has been well documented in patients with intra-abdominal metastases secondary to brain tumors and, less frequently, brain metastases secondary to intra-abdominal tumors. In spite of that, there are few reports of cutaneous metastases along the VP shunt catheter trajectory.

We present the case of a cholangiocarcinoma cutaneous metastasis at the VP shunt trajectory as the first clinical sign of this type of tumor. The patient had undergone the shunt insertion 4 years earlier due to a hydrocephaly secondary to a subarachnoid hemorrhage. After diagnosis, she was referred to chemotherapy and oncology follow-up.

In the literature, 30 cases of cutaneous metastasis of cholangiocarcinoma were reported. Dissemination has been described involving percutaneous biliary drainage and distant sites. However, the case presented in this study alerts us about the possibility of cutaneous metastasis of intra-abdominal tumors in the trajectory of VP shunt catheters.

O colangiocarcinoma representa menos de $2 \%$ das neoplasias malignas. Sua metástase cutânea é extremamente rara, representando $0.0002 \%$ dos casos.

A derivação ventrículo-peritoneal (DVP) tem sido considerada uma via potencial para a disseminação dos tumores. Essa propagação tumoral já foi bem descrita em pacientes com tumores do sistema nervoso central e metástases intra-abdominais e, menos received

April 30, 2017

accepted

September 14, 2017

published online

October 16, 2017
DOI https://doi.org/

10.1055/s-0037-1607343. ISSN 0103-5355.
Copyright $\odot 2017$ by Thieme Revinter

Publicações Ltda, Rio de Janeiro, Brazil
License terms

(c) (i) $\ominus$ (\$) 


\author{
Palavras-chave \\ - Colangiocarcinoma \\ - Derivação \\ ventrículo- \\ peritoneal \\ - Metástase cutânea
}

\begin{abstract}
frequentemente, em metástases cerebrais secundárias a tumores intra-abdominais. Apesar disso, a presença de metástases cutâneas ao longo da trajetória do cateter de DVP é pouco relatada.

Apresentamos o caso de uma paciente portadora de DVP há quatro anos devido a uma hidrocefalia secundária à hemorragia subaracnoide e que apresentou metástases cutâneas de colangiocarcinoma na trajetória do cateter de derivação como o primeiro sinal clínico do tumor. Após o diagnóstico, ela foi encaminhada para quimioterapia e acompanhamento com oncologia.

Na literatura, foram relatados 30 casos de metástases cutâneas de colangiocarcinoma. Em geral, a disseminação pode envolver locais distantes ou cateteres de drenagem biliar percutânea. No entanto, o caso descrito neste estudo nos alerta sobre a possibilidade de metástases cutâneas de tumores intra-abdominais na trajetória de cateteres de DVP.
\end{abstract}

\section{Introduction}

Cholangiocarcinomas are rare tumors originated from the intrahepatic or extrahepatic biliary epithelium. It accounts for less than $2 \%$ of all cancer diagnoses. ${ }^{1}$

Cutaneous metastases from internal malignancies are uncommon, involving $0.7-9 \%$ of all cancer patients. Moreover, cutaneous metastases from cholangiocarcinomas are extremely rare, with an incidence of $0.0002 \%{ }^{2}$

The ventriculoperitoneal (VP) shunt has been reported as being related to intra-abdominal metastases for many types of primary brain neoplasms. ${ }^{3,4}$ Also, there are few case reports on abdominal tumors associated to leptomeningeal dissemination through a VP shunt catheter. ${ }^{5}$ On the other hand, tumor seeding along a VP shunt has been reported in only one case, secondary to a primary central nervous system lymphoma. ${ }^{6}$
In the paper herein, we report a rare case of cholangiocarcinoma seeding along a VP shunt trajectory.

\section{Case Report}

A 71-year-old female patient was diagnosed with normal pressure hydrocephalus secondary to subarachnoid hemorrhage and treated with a ventriculoperitoneal (VP) shunt (-Fig. 1).

At outpatient follow-up, she presented with a small painless inframammary subcutaneous nodule in the trajectory of the VP shunt catheter (-Fig. 2). This was first diagnosed as a granulomatous reaction to the synthetic material. During the year, the lesion persisted and was observed at other points of the catheter (scalp and clavicle region), causing discomfort to the patient.

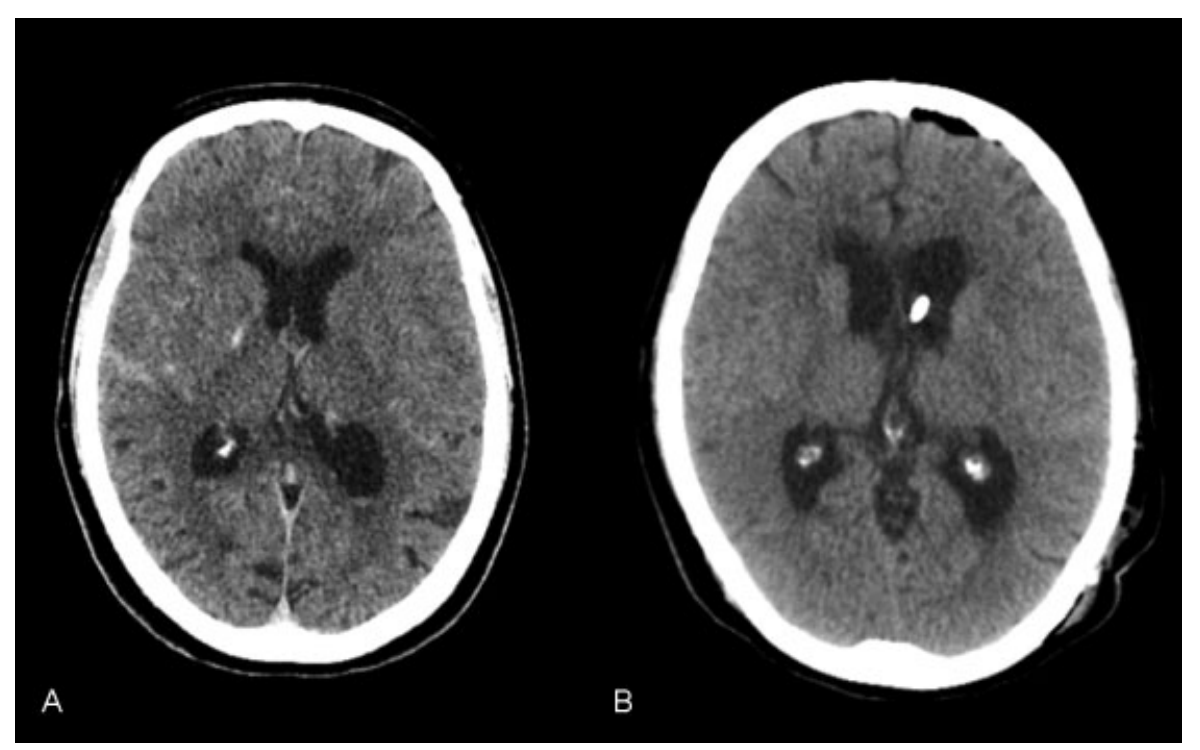

Fig. 1 Axial computed tomography (CT). (A) Preoperative scan demonstrates subarachnoid hemorrhage and hydrocephalus. (B) Postoperative CT showing the adequate positioning of the proximal ventriculoperitoneal shunt catheter. 


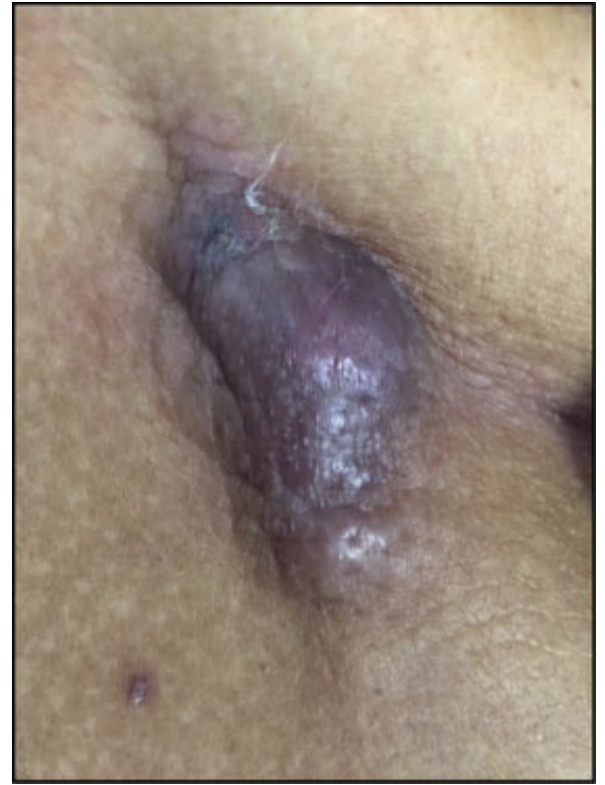

Fig. 2 Inframammary subcutaneous nodule at the trajectory of the ventriculoperitoneal shunt catheter.

Dermatology evaluation suggested as differential diagnoses a chronic infection, sarcoidosis and metastatic lesions. The VP shunt was removed and a skin biopsy was performed. Histology analysis confirmed a metastatic adenocarcinoma. The patient was referred to a cancer institute for oncology evaluation and investigation of the primary malignancy.

The patient was asymptomatic, and reported no complaint of weight loss or abdominal pain. Her past medical history was noncontributory. Apart from the subcutaneous nodules, the findings of the physical examination were normal. Laboratory analyses were normal, except for carbohydrate antigen 19-9 (CA 19-9) $659.6 \mathrm{ng} / \mathrm{mL}$ and carcinoembryonic antigen (CEA) $3.8 \mathrm{ng} / \mathrm{mL}$.

The abdominal computed tomographic scan detected a thickening of the gallbladder and hepatic ducts with invasion of the right hepatic artery and right portal branch (-Fig. 3 ). Ultrasound-guided biopsy of the lesion showed a poorly differentiated adenocarcinoma. Immunohistochemical analysis of the tumor cells were positive for cytokeratin 19 (CK 19), cytokeratin 7 (CK 7) and cytokeratin AE-1/AE3. Based on these findings, a diagnosis of cholangiocarcinoma was made. The patient was referred to oncology for complementary treatment with systemic chemotherapy.

\section{Discussion}

Cutaneous metastases of cholangiocarcinoma are extremely rare and have been reported to occur in only $0.4-5.3 \%$ of cases. ${ }^{7}$ The latest systematic review was published in $2015^{8}$ and reported 30 cases between 1978 and 2014. In this study, the median age at diagnosis was 60 years old.

The literature reports two patterns of skin metastasis, the most common being the one in which cancer cells disseminate through the catheter used for percutaneous biliary

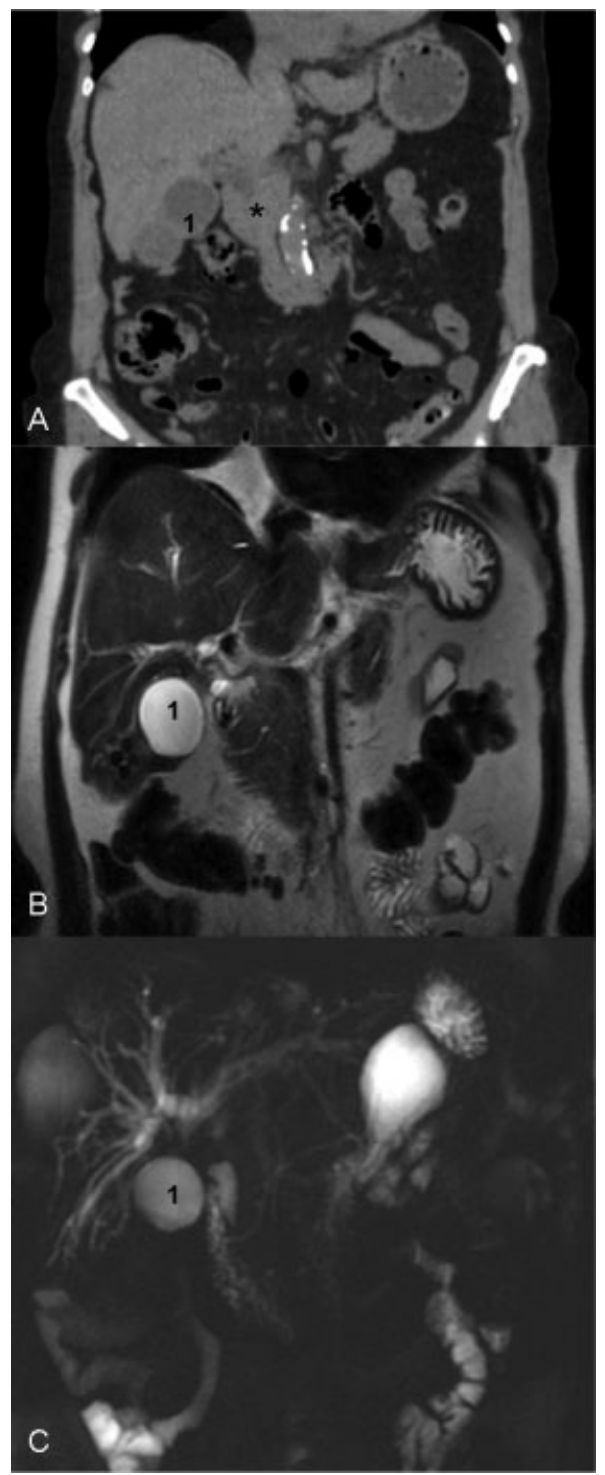

Fig. 3 (A) Coronal view of the abdominal computed tomographic scan demonstrates a thickening of the gallbladder (number 1 ) and hepatic ducts (asterisk). (B) Coronal view of the abdominal T2-weighted magnetic resonance imaging showing dilated gallbladder (number 1 ). (C) Cholangiomagnetic resonance imaging showing dilation of the gallbladder fundus (number 1) and intrahepatic biliary ducts, also thickening of the gallbladder infundibulum and infiltrative tissue extending to confluence of the hepatic ducts.

drainage; the other one is dissemination to distant sites, which shows different tumor behavior. ${ }^{7}$ Regarding distant sites, the most frequently involved is the scalp. $2,7,8$

The incidence of cutaneous metastatic lesions as the first clinical sign of the cancer has been described in only $0.8 \%$ of the patients with systemic malignancies. ${ }^{7}$ However, regarding cutaneous metastasis of cholangiocarcinoma, as in the case reported, the literature review shows an incidence of $27.6 \%^{8}$, suggesting that bile duct examination should be performed for cutaneous metastasis of unknown origin. The most common presentation is a firm, painless nodule of sudden onset and rapid growth (multiple nodules are found in $46.4 \%$ of patients). ${ }^{1}$ Traditionally, cutaneous 
metastases indicate the presence of advanced disease and are associated with poor prognosis. ${ }^{7}$

Theoretically, migration of tumor cells through the silicone catheter surface was demonstrated both in the flow direction of the cerebrospinal fluid (CSF) and in the opposite direction of the CSF fluid from the peritoneum to the other end of the VP shunt catheter. It is not clear whether cells adhered to the inner or outer tubing before migration, because in the case reported the catheter was not available for pathologic evaluation. ${ }^{5}$

In general, factors that influence metastatic dissemination of primary brain tumors after a VP shunt are direct surgery on the tumor immediately prior to the shunt, the period of survival owing to the natural history of the primary intracranial disease and immunosuppressive treatments, such as cranial radiotherapy and prolonged corticosteroid therapy. ${ }^{4}$

On the other hand, tumor seeding along a VP shunt has been reported in only one case secondary to a primary central nervous system lymphoma, but never secondary to an intra-abdominal tumor. ${ }^{6}$ The pathophysiology has not yet been fully elucidated.

To date, to our knowledge, this is the first report of a patient with cutaneous metastasis of cholangiocarcinoma along a VP shunt pathway. ${ }^{6}$

\section{Conclusion}

In summary, cutaneous metastases from cholangiocarcinoma are rare, but do occur. When metastatic skin lesions are discovered, the clinicians should be aware of the possibility that these lesions can be associated with cutaneous metastases of cholangiocarcinoma. ${ }^{7}$ In conclusion, caution is required for cancer patients with indwelling catheters as they may provide artificial routes for tumor dissemination.

Conflict of Interest

On behalf of all authors, the corresponding author states that there is no conflict of interest.

\section{References}

1 Geramizadeh B, Giti R, Malekhosseini SA. Cutaneous metastasis of cholangiocarcinoma: report of two cases. Int J Organ Transplant Med 2013;4(04):172-174

2 West KL, Selim MA, Puri PK. Cutaneous metastatic cholangiocarcinoma: a report of three cases and review of the literature. J Cutan Pathol 2010;37(12):1230-1236

3 Donovan DJ, Prauner RD. Shunt-related abdominal metastases in a child with choroid plexus carcinoma: case report. Neurosurgery 2005;56(02):E412, discussion E412

4 Low YY, Thomas J, Wan WK, Ng WH. Brain metastases as a cause of malignant cerebrospinal fluid ascites: case report and review of the literature. CNS Oncol 2012;1(01):29-37

5 Eralp Y, Saip P, Aydin Z, Berkman S, Topuz E. Leptomeningeal dissemination of ovarian carcinoma through a ventriculoperitoneal shunt. Gynecol Oncol 2008;108(01):248-250

6 Ko J-H, Lu P-H, Tang T-C, Hsu Y-H. Metastasis of primary CNS lymphoma along a ventriculoperitoneal shunt. J Clin Oncol 2011; 29(34):e823-e824

7 Hyun SY, Lee JH, Shin HS, Lee SW, Park YN, Park JY. Cutaneous metastasis from cholangiocarcinoma as the first clinical sign: a report of two cases. Gut Liver 2011;5(01):100-104

8 Liu M, Liu BL, Liu B, et al. Cutaneous metastasis of cholangiocarcinoma. World J Gastroenterol 2015;21(10):3066-3071 